between 20 and 22 weeks, and the multigravida between 16 and 18 weeks. If she only recognizes movements a month later than she should, this suggests that the dates are wrong. This is by no means an accurate method of checking, but it may be useful confirmatory evidence. If there is still doubt an $x$-ray film taken at about 36 weeks is of value. At this time the epiphysis at the lower end of the femur should be clearly visible, and that at the upper end of the tibia may be faintly seen. If it is not visible it suggests that the dates are wrong. The measurement of abdominal girth may also be helpful. At 36 weeks it is usually 36 in. (91 cm.), and at 40 weeks 40 in. $(101.5 \mathrm{~cm}$.). I do not think that taking up of the cervix is necessarily a sign of maturity. This may well occur if premature labour is imminent; and, conversely, in some cases of undoubtedly prolonged pregnancy even at 44 weeks the cervix may not be taken up. I am sure that it is wrong to say that a pregnancy is not prolonged simply because the cervix is not taken up.

Regular antenatal weighing is of considerable help. It has been fashionable for some years to regard an excessive gain in weight as evidence of incipient preeclamptic toxaemia. The value of this is somewhat equivocal, but undoubtedly the woman who loses weight at or about term should be considered seriously as a problem of placental insufficiency; and when the pregnancy according to the menstrual dates is prolonged, loss of weight is clinically highly significant. The woman who has had proper antenatal care from an early date in pregnancy should reach term with the certainty on the part of her attendant that her dates are correct, or with a necessary correction already made-all the evidence of menstrual history, size of the uterus in early pregnancy, the time of first feeling foetal movements, and so on, and if necessary $x$-ray examination at about 36 weeks, having been weighed, and a decision having been reached-before ever she reaches term-that she is due on such and such a date. Term in these cases is often marked by a "false labour." If she passes this date by two weeks, or sooner if she starts to lose weight, I firmly believe that surgical induction of labour is indicated.

\section{Surgical Induction of Labour}

In certain selected cases, that of the elderly primigravida, for instance, elective caesarean section may be preferable. In general, the woman should not be allowed to go more than about two weeks past her dates. If there is any suggestion of hypertension or pre-eclamptic toxaemia, or if the woman is over 30 , it is best to induce labour by the end of 41 weeks at the latest, and often earlier. On the other hand, if a woman is para-1 or para-2 and is young, say under 30 , she can often be left safely to go as far as 43 weeks provided that no toxaemia develops, and there is no loss of weight. As I pointed out in 1954 (Browne, 1954), the combination of prolonged pregnancy and toxaemia or hypertension is particularly lethal to the baby. Many of these women will respond perfectly satisfactorily to simple induction of labour, by which I mean castor oil, an enema, and a warm bath. This should, however, be followed within 24 hours by surgical induction of labour if labour has not already started. If the liquor is scanty, thick, and meconium-stained, a 15-minute count should be made of the foetal heart. Moreover, even if there is plenty of liquor, if the surgical induction of labour does not succeed within 48 to 72 hours caesarean section should be undertaken without hesitation. Hesitation means that the indication for surgical induction of labour was not a sound one, and should never bave been done. From a clinical point of view one of the most useful objective assessments is the maternal weight. If the woman is losing weight the foetus is in danger, and should be delivered.

Is the hazard of surgical induction of labour as Gibberd (1958) has suggested greater than that of postmaturity? Thirty years ago this was true, but not to-day. In any case the tremendous reduction in this country in perinatal mortality due to such things as eclamptic convulsions, placenta praevia, neonatal infections, etc., in the past $\mathbf{3 0}$ years has uncovered prolonged pregnancy as a considerable foetal risk, and makes it imperative that we should not flinch from performing an operation that, properly carried out, now carries but little risk to the life or health of mother or child.

REFERENCES

Ballantyne, J. W. (1902). J. Obstet. Gynaec. Brit. Emp., 2, 521. - and Browne, F J. (1922). Ibid., 29, 177.

Browne, J. C. McClure (1954). La Prophylaxie en Gynécologle et Obstetrique, p. 1018. Georg. Geneva.

et Veall, N. (1953). J. Obstet. Gynaec. Brit. Emp., 60, 141.

Clayton, S. G. (1941). Ibid., 48, 450.

Clifford, S H. (1957). Advanc. Pediat., 9, 13.

Dixon, H. G. (1961). Personal communication.

Elliott, P. M., and Iuman, W. H. W. (1961). Lancet, 2, 835.

Gibberd, G. F. (1958). Ibid., 1, 64.

\section{DANGER OF SUXAMETHONIUM AND ENDOTRACHEAL INTUBATION IN ANAESTHESIA FOR BURNS}

BY

G. H. BUSH, B.M., F.F.A. R.C.S.

H. A. P. GRAHAM, M.B., F.F.A. R.C.S.

A. H. M. LITTLEWOOD, M.B., F.R.C.S.

AND

L. B. SCOTT, M.B., F.R.C.S.Ed.

From the Burns and Plastic Units, Whiston Hospital, Lancs, and Alder Hey Hospital, Liverpool

The problems of anaesthesia for burns have been well reviewed by Middleton (1957), Shannon (1957), and Middleton and Wolfson (1958). It has been stated (Middleton, 1957) that anaesthesia should provide a considerable degree of analgesia and a light plane of narcosis to produce rapid awakening at the termination of the operative procedure. These broad principles would be accepted by all anaesthetists, but controversy still exists over the technique and agents of choice. Intubation is often required to ensure full control of the airway. Middleton (1957) strongly advocates endotracheal anaesthesia, and in a series of 502 anaesthetics 497 were intubated, though 3 cases developed severe laryngotracheitis necessitating tracheostomy. It has been suggested that the patient should be intubated using either cyclopropane (Middleton, 1957) or suxamethonium (Middleton and Wolfson, 1958). The danger of intubation in cases of burns is apparent from several reports (Moncrief, 1958 ; Masters, Hansen, and Robinson, 1959 ; Finer and Nylén, 1959 ; Forrest, 1959 ; 
Fleming, Hueston, Stubbe, and Villiers, 1960) which have stressed the occurrence of cardiac arrest.

A recent report by Finer and Nylén (1961) has stressed the increased incidence of cardiac arrest in burned patients $(1: 209)$ compared with the incidence in patients undergoing other plastic operations $(1: 2,744)$. Of significance is the finding that in all the published cases cardiac arrest occurred between the 21st and 50th days after the burn. Finer and Nylén suggest that hypnotic or local analgesia should be considered if further surgery is required in a case of successfully treated cardiac arrest, and describe the management of such a case. The purpose of this paper is to describe two further cases of cardiac arrest occurring during the induction of anaesthesia in severe burns and to draw conclusions concerning the aetiology and prophylaxis of this complication.

\section{Case 1}

A 19-year-old youth sustained full-thickness burns to both legs and buttocks totalling $25 \%$ of the body surface. Twenty-seven days later, on January 14, 1960, he was thought fit for skin grafting. The general condition was good but he was extremely apprehensive. Premedication with morphine $10 \mathrm{mg}$. and atropine $0.6 \mathrm{mg}$. was given 45 minutes before anaesthesia was induced with intravenous thiopentone $250 \mathrm{mg}$. together with atropine $0.6 \mathrm{mg}$. followed by suxamethonium $50 \mathrm{mg}$. The patient was intubated and the lungs were inflated with a mixture of nitrous oxide and oxygen with $0.5 \%$ halothane. Within a few minutes of induction the patient was noticed to be pale and the carotid pulse felt weak and rapid. After he was wheeled into the theatre no arterial pulsations could be detected. An incision was made in the left fifth intercostal space and the heart was found to be in asystole. It was estimated that circulatory arrest lasted for two to three minutes before cardiac massage was instituted, and after 30 seconds the heart contracted spontaneously, rapidly recovering normal force and rhythm. The chest was closed without drainage and the operation postponed. Consciousness returned that evening and no ill effects were noted.

On January 28 the general condition was good, but, not surprisingly, the patient was even more apprehensive than on the previous occasion. Promethazine $50 \mathrm{mg}$. and atropine $0.9 \mathrm{mg}$. were given 45 minutes before anaesthesia was induced with thiopentone $125 \mathrm{mg}$. followed by suxamethonium $25 \mathrm{mg}$. The lungs were inflated with a mixture of nitrous oxide and oxygen. The pulse was felt continuously during the induction and found to be irregular in rate and rhythm immediately after the intravenous suxamethonium. A second dose of suxamethonium $25 \mathrm{mg}$. was given and on this occasion the pulse suddenly ceased. The trachea was then intubated. Despite thumping of the praecordium the pulse did not return. The chest wound was reopened and again the heart was found to be in asystole. Massage restored cardiac action in 30 seconds. On this occasion circulatory arrest lasted for less than two minutes. The chest was closed and a drain connected to an underwater seal. Split skin grafts were taken and the patient was returned to the ward. Consciousness returned the same evening and again no ill effects from the cerebral hypoxia were noted.

The post-operative course was complicated by a bronchopleural fistula and a pericardial effusion, and he was not regarded as being fit enough for further grafting for two months.

On March 28 he was fretful and uncooperative despite papaveretum $20 \mathrm{mg}$. and hyoscine $0.4 \mathrm{mg}$. given 45 minutes before operation. Anaesthesia was induced with pethidine $50 \mathrm{mg}$. intravenously followed by preoxygenation and then nitrous oxide. A test dose of gallamine $40 \mathrm{mg}$. was followed by a further $120 \mathrm{mg}$., the larynx was sprayed with $4 \%$ lignocaine and an endotracheal tube passed into the trachea.
Ventilation was controlled by using a mixture of nitrous oxide and oxygen. A further $80 \mathrm{mg}$. of gallamine was required during the procedure. Split skin grafts were taken and granulations removed from the unhealed areas. Electrocardiographic monitoring during the induction showed no alteration in cardiac rate or rhythm. Atropine $1.2 \mathrm{mg}$ followed by neostigmine $1.5 \mathrm{mg}$. in divided doses produced adequate spontaneous respiration. Immediate post-operative restlessness was controlled by pethidine $50 \mathrm{mg}$. intravenously, and he was returned to the ward in good condition.

The grafts were applied 48 hours later and healed well. The chest wound finally healed six months after the second thoracotomy.

\section{Case 2}

A 31-year-old man sustained burns of the abdomen, both legs, neck, and genitalia totalling $45 \%$ of the body surface, when he lit a cigarette near magnetic ink (highly flammable blue magnesium).

Fourteen days later, on August 30, 1961, 30 minutes after atropine $0.6 \mathrm{mg}$., the patient was anaesthetized with oxygen, nitrous oxide, and halothane. The burnt areas were cleaned and dressed. A similar anaesthetic technique was used on September 6, when the burnt areas were desloughed and the upper limbs grafted.

On September 13 atropine $0.6 \mathrm{mg}$. was given intravenously followed by thiopentone $50 \mathrm{mg}$. Because of a burning pain at the site of the injection induction was completed with cyclopropane and oxygen. Suxamethonium $50 \mathrm{mg}$. enabled intubation to be performed easily. Anaesthesia was maintained with nitrous oxide, oxygen, and halothane. The grafts were dressed and the burnt areas further desloughed.

On September 20 the patient was induced with atropine $0.6 \mathrm{mg}$. and thiopentone $200 \mathrm{mg}$., and anaesthesia was maintained with nitrous oxide, oxygen, and halothane while extensive areas of the trunk were covered with grafts.

On October 11, 55 days after the burn, further grafting was thought to be necessary. The patient was acutely anxious. Anaesthesia was induced with atropine $0.6 \mathrm{mg}$., thiopentone $200 \mathrm{mg}$., and suxamethonium $50 \mathrm{mg}$. The lungs were inflated with nitrous oxide, oxygen, and minimal halothane, and an endotracheal tube was passed. Almost immediately cardiac arrest was diagnosed. Oxygen only was administered and the head of the table lowered. An incision was made in the fifth left intercostal space. The heart was found to be in asystole and after two and a half minutes of circulatory arrest cardiac massage was started. After approximately three minutes ventricular fibrillation occurred. An intracardiac injection of $250 \mu \mathrm{g}$. of adrenaline and the use of the cardiac defibrillator stopped the fibrillation, which recurred five minutes later and a further shock was required. After further massage weak cardiac contractions began and thereafter the heart continued to beat normally. Anaesthesia was recommenced with nitrous oxide, oxygen, and $0.5 \%$ halothane because of movement of the patient. The chest was closed and a drain connected to an underwater seal. Split skin grafts were then taken from both lower legs. The patient was restless on return to the ward, but four hours later was able to speak, and the next day was completely conscious and rational.

A week later the stored skin was applied without the need for any anaesthesia. Subsequently the patient made a slow but satisfactory recovery.

\section{Discussion}

Cardiac arrest may occur in any type of surgical condition, but these two cases bear remarkable resemblance to those described by Finer and Nylén (1959), Forrest (1959), and Fleming et al. (1960). All the patients were suffering from severe burns; all had a cardiac arrest during induction of anaesthesta at a similar stage of their treatment; suxamethonium was always used and intubation usually performed. Recovery was the rule. 
This combination of factors suggests that the mechanism of the arrest was identical in each case, particularly since this complication did not arise in previous or subsequent anaesthetics when different techniques were used. The fact that three patients suffering from burns each sustained two episodes of cardiac arrest suggests that patients with burns are prone to this severe complication. The possible reasons for this are discussed later.

The Table shows the details of the procedures in the eight incidents of cardiac arrest described by three authors and in this paper, and illustrates the common denominators.

In the case described by Finer and Nylen (1959) the first three anaesthetics were uneventful, but, although a similar technique was used for the next anaesthetic, cardiac arrest occurred on induction. It should be noted that the patient was extremely anxious, that hyoscine was used in the premedication, and that 100 mg. of suxamethonium was administered. The fifth anaesthetic was uncomplicated but differed from the previous administrations in that atropine was used in the premedication, that $200 \mathrm{mg}$. of suxamethonium was given in divided doses, and that endotracheal intubation was not performed. During induction of the subsequent anaesthetic cardiac arrest again occurred; on this occasion endotracheal intubation was performed using suxamethonium $50 \mathrm{mg}$. These authors attributed the cardiac asystole to an increased reflex excitability due to extreme anxiety coupled with a viscero-cardiac reflex from intubation (Keating, 1956), since cardiac arrest did not occur when intubation was not performed.

Forrest (1959) described an episode of cardiac arrest in a 14-year-old girl during induction of anaesthesia for skin grafting. On this occasion suxamethonium was used instead of $\mathrm{D}$-tubocurarine to facilitate endotracheal intubation. The vocal cords were sprayed with lignocaine. Although absorption of local anaesthetic agents applied to the tracheobronchial tree is extremely rapid, the dose used $(0.6 \mathrm{mg} . / \mathrm{kg}$. $)$ is well within the accepted safety margin (Bromage and Robson, 1961). Forrest attributed the cardiac arrest to a subnormal blood volume associated with a fall in blood-pressure due to thiopentone and the introduction of positive-pressure

Details of Procedures Used in Eight Incidents of Cardiac Arrest

\begin{tabular}{|c|c|c|c|c|c|c|c|c|c|c|}
\hline $\begin{array}{l}\text { Refer- } \\
\text { ence }\end{array}$ & $\begin{array}{l}\text { Date of } \\
\text { Anaes- } \\
\text { thetic }\end{array}$ & Premed. & $\begin{array}{c}\text { Time } \\
\text { (Minutes) }\end{array}$ & Induction & Relaxant & $\begin{array}{l}\text { Anaes- } \\
\text { thetic } \\
\text { Agents }\end{array}$ & $\begin{array}{l}\text { Intu- } \\
\text { bation }\end{array}$ & Lubricant & $\begin{array}{c}\text { Condition } \\
\text { of } \\
\text { Heart }\end{array}$ & Comment \\
\hline $\begin{array}{l}\text { Finor and } \\
\text { Ny'én } \\
\text { (1959) }\end{array}$ & $\begin{array}{cr}\text { Mar. } & 12 \\
\text {, } & 14 \\
\text { ", } & 20 \\
& 21 \\
\text { " } & 26 \\
& \\
& \\
\text {, } & 27\end{array}$ & $\begin{array}{c}? \\
? \\
? \\
\text { Morphine } 10 \mathrm{mg} . \\
\text { Hyoscine } 0.3 \mathrm{mg} . \\
\text { Pethidine } 100 \mathrm{mg} . \\
\text { Atropine } 0.5 \mathrm{mg} . \\
\text { Promethazine } \\
50 \mathrm{mg} \text {. } \\
\text { Chlorpromazine } \\
25 \text { mg. } \\
\text { Morphine } 10 \mathrm{mg} . \\
\text { Hyoscine } 0.3 \mathrm{mg} .\end{array}$ & $\begin{array}{l}? \\
? \\
? \\
? \\
?\end{array}$ & $\begin{array}{l}\text { "Narkotal" } \\
\qquad ", \\
\text { Narkotal } 300 \mathrm{mg} . \\
\qquad \mathrm{N}_{2} \mathrm{O} / \mathrm{O}_{2} \\
\\
\text { Chlorpromazine } \\
10 \text { mg. } \\
\text { Pethidine } 50 \mathrm{mg} . \\
\text { Narkotal } \\
300 \text { mg. }\end{array}$ & $\begin{array}{l}\text { Suxamethonium } \\
\text { ? dose } \\
\text { ", } \\
\text { Suxamethonium } \\
100 \mathrm{mg} \text {. } \\
\text { Suxamethnnium } \\
\text { up to } 200 \mathrm{mg} \text {. } \\
\text { Suxamethonium } \\
50 \mathrm{mg} \text {. }\end{array}$ & $\begin{array}{c}\text { Pethidine, } \\
\mathrm{N}_{2} \mathrm{O}, \mathrm{O}_{2} \\
\text { "’ } \\
\mathrm{N}_{2} \mathrm{O}^{\prime \prime} \mathrm{O}_{2} \\
\\
\text { Pethidine, } \\
\mathrm{N}_{2} \mathrm{O} \mathrm{O}_{2} \\
\\
\mathrm{~N}_{2} \mathrm{O}_{2}^{\prime} \mathrm{O}_{2}\end{array}$ & $\begin{array}{l}\text { Yes } \\
\text { ", } \\
\text { "' } \\
\text { No }\end{array}$ & $\begin{array}{l}? \\
? \\
? \\
? \\
-\end{array}$ & $\begin{array}{c}\text { No arrest } \\
\quad, \\
\text { Asystole } \\
\text { No arrest }\end{array}$ & 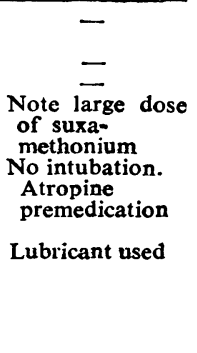 \\
\hline $\begin{array}{l}\text { Forrest } \\
\text { (1959) }\end{array}$ & \begin{tabular}{c|} 
Mar. 12 \\
," 18 \\
31 \\
Apr. 8-25
\end{tabular} & $\begin{array}{c}\text { Quinalbarbitone } \\
120 \mathrm{mg} . \\
\text { Morphine } 10 \mathrm{mg} . \\
\text { Atropine } 0.6 \mathrm{mg} . \\
\text { ", }\end{array}$ & $\begin{array}{l}90 \\
75\end{array}$ & $\begin{array}{l}\text { Thiopentone } \\
200 \mathrm{mg} \text {. }\end{array}$ & $\begin{array}{l}\text { D-Tubocurarine } \\
30 \text { mg. } \\
\text { Suxamethonium } \\
40 \text { mg. } \\
\text { D-Tubocurarine }\end{array}$ & $\mathrm{N}_{2} \mathrm{O} / \mathrm{O}_{2}$ & Yes & $\begin{array}{c}\text { Lignocaine } \\
\text { spray } \\
30 \mathrm{mg} . \\
\text { No }\end{array}$ & Asystole & $\begin{array}{l}\text { - } \\
\text { Differs from pre- } \\
\text { vious anaesthe- } \\
\text { tics in use of } \\
\text { suxamethon- } \\
\text { ium and spray } \\
\quad\end{array}$ \\
\hline $\begin{array}{l}\text { Fleming } \\
\text { et al. } \\
\text { (1960) }\end{array}$ & 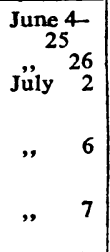 & $\begin{array}{l}\text { Six general anaesth } \\
\text { General anaestheti } \\
\text { Papaveretum } \\
10 \mathrm{mg} \text {. } \\
\text { Hyoscine } 0.2 \mathrm{mg} \text {. } \\
\text { Hyoscine } 0.2 \mathrm{mg} \text {. } \\
\text { Hyoscine } 0.3 \mathrm{mg} \text {. }\end{array}$ & 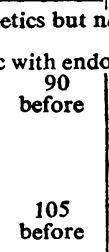 & $\begin{array}{l}\text { o details } \\
\text { Thiopentone } \\
120 \text { mg. }\end{array}$ & $\begin{array}{l}\text { Suxamethonium } \\
50 \mathrm{mg} \text {. } \\
\mathrm{Nil} \\
\text { Suxamethonium } \\
40 \mathrm{mg} \text {. }\end{array}$ & $\begin{array}{c}\mathrm{N}_{2} \mathrm{O} \mathrm{O}_{2}, \\
\text { minimal } \\
\text { trilene } \\
\mathrm{N}_{2} \mathrm{OOO}_{2}, \\
\text { minimal } \\
\text { ether } \\
\mathrm{N}_{2} \mathrm{O} \mathrm{O}_{2}\end{array}$ & $\begin{array}{l}\text { Yes } \\
\text { No } \\
\text { Yes }\end{array}$ & $\begin{array}{c}2 \% \\
\text { Amethocaine } \\
\text { No } \\
,,\end{array}$ & $\begin{array}{l}\text { Fibrillation } \\
\text { No arrest } \\
\text { Fibrillating }\end{array}$ & $\begin{array}{l}\text { No intubation. } \\
\text { No suxa- } \\
\text { methonium }\end{array}$ \\
\hline Case 1 & $\begin{array}{l}\text { Jan. } 14 \\
\text {, } 28 \\
\text { Mar. } 28\end{array}$ & $\begin{array}{l}\text { Morphine } 10 \mathrm{mg} . \\
\text { Atropine } \\
0.6 \mathrm{mg} \text {. } \\
\text { Promethazine } \\
50 \mathrm{mg} \text {. } \\
\text { Atropine } 0.9 \mathrm{mg} \text {. } \\
\text { Papaveretum } \\
20 \mathrm{mg} . \\
\text { Hyoscine } 0.4 \mathrm{mg}\end{array}$ & $\begin{array}{c}45 \\
\text { before } \\
45 \\
\text { before } \\
\\
45 \\
\text { before }\end{array}$ & $\begin{array}{l}\text { Atropine } 0.6 \mathrm{mg} . \\
\text { Thinpentone } \\
250 \mathrm{mg} \text {. } \\
\text { Thinpentone } \\
125 \mathrm{mg} . \\
\\
\text { Pethidine } 50 \mathrm{mg} \text {. } \\
\mathrm{O}_{2}^{\prime} \mathrm{N}_{2} \mathrm{O}\end{array}$ & $\begin{array}{l}\text { Suxamethonium } \\
50 \mathrm{mg} \text {. } \\
\text { Suxamethonium } \\
25 \mathrm{mg} \text {. } \\
\text { Suxamethonium } \\
25 \mathrm{mg} \text {. } \\
\text { Gallamine } \\
160 \mathrm{mg} \text {. }\end{array}$ & $\begin{array}{l}\mathrm{N}_{2} \mathrm{OO}_{2} \\
\text { halothane } \\
0.5 \% \\
\mathrm{~N}_{2} \mathrm{O}^{\circ} \mathrm{O}_{2} \\
\\
\mathrm{~N}_{2} \mathrm{O}^{\prime} \mathrm{O}_{2}\end{array}$ & , & $\begin{array}{c}4 \% \\
\text { Lignocaine }\end{array}$ & $\begin{array}{c}\text { Asystole } \\
\quad, \\
\text { No arrest }\end{array}$ & $\begin{array}{l}\text { Arrest occurred } \\
\text { before intuba- } \\
\text { tion }\end{array}$ \\
\hline Case 2 & $\begin{array}{cr}\text { Aug. } & 30 \\
\text { Sept. } & 6 \\
,, & 13 \\
& \\
\text {, } & 20 \\
\text { Oct. } & 11\end{array}$ & $\begin{array}{l}\text { Atropine } 0.6 \mathrm{mg} \text {. } \\
\text { i.v. } \\
\text { ", } \\
\text { ", }\end{array}$ & & $\begin{array}{l}\text { Thiopentone } \\
50 \mathrm{mg} \text {. } \\
\text { Cyclopropane } \\
\text { Thiopentone } \\
200 \mathrm{mg} . \\
\text { ", }\end{array}$ & $\begin{array}{l}\text { Suxamethonium } \\
50 \mathrm{mg} \text {. } \\
\text { Nil } \\
\text { Suxamethonium } \\
50 \mathrm{mg} \text {. }\end{array}$ & 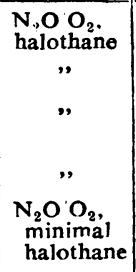 & $\begin{array}{c}\text { No } \\
\text {, } \\
\text { Yes } \\
\text { No } \\
\text { Yes }\end{array}$ & - & $\left\{\begin{array}{c}\text { No } \\
\text { arrest } \\
", \\
\text { Asystole }\end{array}\right.$ & \\
\hline
\end{tabular}


ventilation. It should be emphasized that the substitution of suxamethonium for D-tubocurarine and the spraying of the vocal cords with a small amount of lignocaine were the only variations in a technique that previously and subsequently was entirely innocuous.

Fleming et al. (1960) concluded that the second cardiac arrest in their patient was undoubtedly due to vagal stimulation induced by intubation, because the heart was heard to slow and become irregular during the passage of the tube into the trachea. The arrest on the first occasion may have been due to the same mechanism, since carotid pulsations ceased within a few minutes of induction. It is interesting that between these two episodes an uneventful anaesthetic had been administered during which neither suxamethonium nor intubation was used. These authors suggested that the metabolic disturbances in a patient with severe toxaemia from burns potentiate the response to harmful viscerocardiac reflexes, and that if intubation is required atropine should be administered to limit these vagal reflexes.

In Case 1 the cardiac asystole on the second occasion was related to the administration of suxamethonium and had already taken place before endotracheal intubation was performed, and could therefore be attributed to a toxic effect of this drug. The rapid return of normal cardiac action coupled with asystole occurring within a few minutes of induction suggests that a similar mechanism was responsible for the first episode of cardiac arrest.

The causation of cardiac arrest in Case 2 cannot be stated with certainty. Asystole during induction and the fairly rapid recovery of normal cardiac action suggests vagal overactivity, despite the administration of atropine $0.6 \mathrm{mg}$. intravenously before induction.

\section{Aetiology}

Possible factors in the aetiology of the cardiac arrest in these cases must be briefly discussed. An interesting feature of all these patients is that this complication occurred at a stage in the treatment when the greatest degree of toxaemia was present. A slow recovery of cardiac action was to be expected if myocardial failure, due to a toxic myocarditis and the use of depressant anaesthetic drugs, was primarily responsible for the cardiac arrest. However, this was not so in our cases. The influence that toxicity is thought to have had on the condition is considered later.

Gray (1959) has suggested that insufflation of a high concentration of volatile anaesthetic agents during a period of paralysis, after the use of a relaxant drug, may produce cardiac arrest. This mechanism cannot have occurred in all these cases, since on three occasions when a volatile agent was insufflated only minimal concentrations were used, and on five occasions no volatile agent was administered.

Positive-pressure respiration in the presence of a low blood volume will impede venous return, reduce cardiac output, and produce cardiac standstill. This mechanism is unlikely to have played a major part in these cases, since the blood volume in burned patients remains near normal after the fourth day unless the patient is dehydrated or has a rapid loss of blood on the operating-table (D. MacG. Jackson, 1961, personal communication). It is interesting that the second arrest in the case described by Finer and Nylén (1959) happened the day after giving an anaesthetic, and this sequence of events was present also in the second arrest in the case reported by Fleming et al. (1960). Deprivation of oral fluids that must have taken place in these instances cannot have lowered the blood volume unless there was also acute fluid loss without replacement; there is no evidence to suggest this. Nevertheless any tendency to dehydration should be avoided, by withholding fluids before anaesthesia for the minimum time compatible with safety and restarting oral fluids as soon as possible after operation.

The most plausible explanation of these episodes of cardiac arrest is that vagal stimulation resulted from the administration of suxamethonium and endotracheal intubation. Since publication of the report by Bullough (1959) that suxamethonium administration may cause bradycardia, Lupprian and Churchill-Davidson (1960) have demonstrated that intravenous suxamethonium produced alterations in both rate and rhythm and that these effects may be abolished by the prior administration of atropine. Suxamethonium is believed to produce stimulation of the vagal ganglia due to a nicotinic action.

Changes in cardiac rate and rhythm during intubation have been noted by many workers (Reid and Brace, 1940 ; Johnstone, 1955 ; Rollason and Hough, 1957 ).

If the suggested explanation is correct vagal overactivity must be postulated in cases of burns, because intubation with suxamethonium is a widely used technique yet cardiac arrest is an extremely rare event. Fleming et al. (1960) incriminated intubation as the triggering action in producing vagal stimulation, but we would like to suggest that suxamethonium administration may be equally important. This is well illustrated in Case 1, in which cardiac arrest followed suxamethonium administration, before intubation was performed.

\section{Factors in Increase of Vagal Activity}

A number of factors may explain the increase in vagal tone in these cases. One common finding in our cases, and specifically mentioned by Finer and Nylén in their series, was that the patients were extremely apprehensive, which is hardly surprising in view of their repeated traumatic experience. Anxiety is known to potentiate a vasovagal attack and will undoubtedly enhance vagal activity.

Liver dysfunction occurs in burnt patients, resulting from the persistent infection of the areas of skin loss, and can be assessed by the determination of the pseudocholinesterase level. In a recent study (Bush and Stead, unpublished observations, 1961) a fall in pseudocholinesterase level was demonstrated within a few days of sustaining burns, reaching its lowest level at the time of the greatest degree of toxaemia, which coincides with the period when cardiac arrest seems most likely to occur. A given dose of suxamethonium will therefore produce a more intense and prolonged effect, since normally this drug is broken down rapidly by pseudocholinesterase.

True cholinesterase is also synthesized by the liver, and damage to this organ could result in a lowered concentration at cholinergic receptor sites. If this were so, an increased activity of released acetylcholine, and therefore vagal potentiation, would result.

In any toxic state the reserves of the body are lowered and all organs will be affected. In these circumstances 
the heart will be more affected by hypoxia, heavy dosage with drugs, or other physiological or pharmacological insults, and it can be well appreciated that its irritability will also be increased (Reid and Brace, 1940).

Fleming et al. (1960) have drawn attention to the fact that in their case hyoscine rather than atropine was used as a vagolytic drug prior to both episodes of cardiac arrest and also in those described by Finer and Nylen. In the first episode in Case 1 and in Case 2 atropine $0.6 \mathrm{mg}$. was given intravenously prior to induction, yet cardiac asystole occurred. This does not invalidate the thesis that vagal overactivity is the cause of the arrest, because Goodman and Gilman (1955) state that atropine $2 \mathrm{mg}$. is required to prevent the effects of vagal stimulation on the heart. Rollason (1957) pointed out that atropine $0.6 \mathrm{mg}$. intravenously did not always produce a tachycardia. Morton and Thomas (1958) confirmed that this dose is only just within the accelerating range, but in a small proportion of cases a bradycardia may be produced. Therefore in a person with increased vagal activity it is possible that atropine in a dose of $0.6 \mathrm{mg}$. may in fact enhance rather than prevent the effects of suxamethonium and intubation on the heart.

\section{Conolusions}

The most likely cause of cardiac arrest occurring during induction of anaesthesia in cases of burns is enhanced vagal activity produced either by the administration of suxamethonium or by intubation. This complication can be prevented by the administration of a large dose of intravenous atropine prior to the induction of anaesthesia.

Apprehension should be allayed by careful management and suitable premedication. A phenothiazine derivative such as trimeprazine tartrate is of great value, as it can be given orally and is more pleasant for the patient. It avoids the difficulty often experienced in finding suitable sites for repeated injections, it has an anti-emetic action, and it produces minimal depression of the vital actions.

If suxamethonium is required, only a small dose should be given, because the effect of this drug is greater and is extended in burned patients, since their pseudocholinesterase level is reduced by liver dysfunction.

A further reason for enhanced vagal activity in burned patients is a suspected reduction in true cholinesterase. This may account for the finding that these patients are very resistant to the non-depolarizing relaxants.

Great care should be taken to prevent physiological or pharmacological insults such as drug overdosage, hypoxia, excessive intrapulmonary pressure, and hypercarbia, which are poorly tolerated by a system already weakened by severe toxaemia.

Should cardiac arrest occur and be successfully treated the opportunity of completing the operation should be taken and carried out as expeditiously as possible.

\section{Summary}

Two cases are described in which cardiac arrest developed during induction of anaesthesia for burns; in one case cardiac arrest occurred on two occasions.

It is suggested that vagal overactivity resulting from suxamethonium administration and endotracheal intubation is the most likely explanation for these episodes of cardiac arrest. A review of the literature reveals other incidents of cardiac arrest occurring under similar circumstances in cases of burns.

Enhanced vagal activity is believed to occur in cases of burns, and the possible reasons for this are discussed.

Prophylactic measures are suggested which should avoid this serious complication.

We are grateful to Dr. B. Kay for the anaesthetic details of Case 2. The assistance given by Mr. R. Edwards, consultant thoracic surgeon, Broadgreen Hospital, Liverpool, and his senior registrar, Mr. B. D. Leckie, in deallng with the post-operative chest complications in Case 1 is gratefully acknowledged. Thanks are due to Mr. R. G. Pulvertaft for allowing one of us (L.B.S.) to treat the cardiac arrest in the patient under his care (Case 2).

ADDENDUM.-Since this paper was written it has been learnt from another hospital that four months after his episode of cardiac arrest Case 2 suffered a further episode of cardiac arrest during induction of anaesthesia for grafting of a small unhealed area. A similar anaesthetic technique using endotracheal intubation of suxamethonium was employed. Cardiac massage rapidly restored normal action and the patient has now returned to work.

REFERENCES

Bromage,, P. R., and Robson, J. G. (1961). Anaesthesia, 16, 461

Bullough, J. (1959). Brit. med. J., 1, 786.

Finer, B. L., and Nylén, B. O. (1959). Ibid., 1, 624.

Fleming (1961). Plast. reconstr. Surg., 27, 49.

J. Bueston, J. T., Stubbe, J. L., and Villiers,

J. D. (1959) Brit med. J.. 1, 157.

Goodman, L. S., and Gilman, A. (1955). The Pharmacological Basis of Therapeutics, 2nd ed., p. 546. Macmillan, New

Gray, T. C. (1959). In General Anaesthesia, edited by Frankis T. Evans and Cecil Gray, vol. 1, p. 422. Butterworth, London.

Johnstone, M. (1955). Anaesthesia, 10, 122.

Keating, V. (1956). Anaesthetic Accidents, p. 42. Lloyd Luke, London.

Lupprian, K. G., and Churchill-Davidson, H. C. (1960). Brit. med. J., 2, 1774.

Masters, F.' W., Hansen, J. M., and Robinson, D. W. (1959). Plast. reconstr. Surg., 24. 472.

Middleton, H. G. (1957). Proc. roy. Soc. Med.. 50, 888.

and Wolfson, L. J. (1958). Brit. med. Bull., 14, 42.

Moncrief, J. A (1958). Ann. Surg., 147, 443.

Morton, H. J. V., and Thomas, E. T. (1958). Lancet, 2, 1313.

Reid, L. C., and Brace, D. E. (1940). Surg. Gynec. Obstet., 70, 157.

Rollason, W. N. (1957). Anaesthesia, 12, 364.

and Hough, J. M. (1957). Brit. J. Anaesth., 29, 363. Shannon, D. W.'(1957). Proc. roy. Soc. Med., 50, 885.

The Oxford University Gazette (October 4) says: "As the result of a conference organized in Oxford in December, 1961, by the Nuffield Provincial Hospitals Trust to discuss ways in which postgraduate medical education could be developed in Regional Board hospitals (i.e., outside the teaching hospitals proper) the trustees set aside a sum of $£ 250,000$ for the support of schemes for promoting postgraduate studies in the provincial non-teaching hospitals. The University has now joined with the Oxford Regional Hospital Board in submitting an application to the trustees for a grant in aid of a programme of development in the Oxford region over a five-year period. the principal feature of which would be the appointment at each main hospital centre of a member of the senior medical staff as part-time 'clinical tutor' whose duty would be to co-ordinate local activities and act as a link with the University. Library facilities would be improved, special items of equipment needed for demonstrations and lectures provided, and a fund set up from which special educational grants could be made. The role of the University in these developments would be mainly advisory, and the Committee for Postgraduate Medical Studies would assist in the administration of any grant made by the Trust. Partly as a corollary of these proposals. the composition and function of the committee is at present under review." 